\title{
SLAVIC ACTIVISTS \\ AND SOCIO-POLITICAL SITUATION IN BOSNIA \\ AT THE TURN OF THE 19TH CENTURY. THE FOUNDATIONS \\ OF THE CONTEMPORARY ETHNIC DIVISIONS
}

\author{
JĘDRZEJ PASZKIEWICZ
}

\begin{abstract}
AвSTRACT. The aim of the article is to show the forms and content of public and political activity of the Slavic elites in Bosnia and Herzegovina during the time of Habsburg rule (1878-1914). The research into the press releases and academic publications allows to show the most prominent circles and individuals who aspired to be the representatives of the people, defined in accordance with ethnic and religious divisions.

These groups are characterised via an analysis of the correlation between the socio-political circumstances in Bosnia and the external influences (such as ideologies, personal and organisation relations, the impact of the state authorities). The political stances among the most prominent circles are portrayed in the context of the legal and institutional solutions regarding Bosnia, as well as the ethnic and religious policy of the Habsburg administration.
\end{abstract}

Author: Jędrzej Paszkiewicz, Adam Mickiewicz University, Faculty of History, Uniwersytetu Poznańskiego st. 7, 61-614 Poznań, Poland, prosinac@amu.edu.pl, ORCID iD: https://orcid.org/0000-0002-7115-9284

Keywords: Bosnia, Austro-Hungary, ethnic division

Balcanica Posnaniensia. Acta et studia, XXVII, Poznań 2020, Wydawnictwo Wydziału Historii UAM, pp. 123136, ISBN 978-83-66355-54-5, ISSN 0239-4278. English text with summary in English.

doi.org/10.14746/bp.2020.27.8

The purpose of the article is to outline the beliefs of the representatives of South Slavic Bosnian elites active during the 1878-1914 period, in the context of their approach to the social and political situation in Bosnia. The elites in question were active in the fields of literature, culture and social politics. Predominantly, they would identify with the Muslim, Orthodox or Catholic community, all of which had been subject to an intense process of modernisation since the 1860s. This phenomenon, having begun during the Ottoman rule, was a result of the dynamic social and geopolitical transformations within the region, which had naturally impacted on Bosnia. These transformations in turn had been triggered by the territorial expansion, pursued at the expense of the Osman Empire by the multi-national Habsburg Monarchy and the Principality of Serbia (or since 1881, the Kingdom of Serbia). The escalating strife for territory and political influence between the regional powers caused massive change in the 
perceived identities among the local communities ${ }^{1}$. During this period, the defining characteristics of Bosnian Slavs underwent a tremendous transformation. Under the Osman rule they had followed the religious criterion, with the topmost position attributed to the Muslims. Under the Habsburgs on the other hand, the followers of Islam lost their privileged status, but retained their religious distinctiveness, based on the institutions and separate regulations which had previously been in place. In the new reality, the Christians, both Orthodox and Catholic, also struggled to achieve a separately defined status, in both the religious as well as the legal and political sphere.

A the very beginnings of the Habsburg occupation in 1878, Bosnia became subject to the implementation of various social, political and ideological novelties, with regards to the practical functioning of the multi-ethnic Monarchy. The administrative apparatus, which had to be established from the ground up, was dominated by foreigners, while locals were employed as lower-rank officials. The young generation, born in Bosnia during the latter half of the 19th century, became the forming foundation of the new social elite, identified with the interests and identity of the local Slavic communities. They were sparse, but gladly broad-minded, having acquired higher education in Vienna, Budapest, Zagreb or Belgrade. As their cultural formation had taken place in rivalled centres, they faced the inevitable necessity to establish their views and new cultural codes, applicable to the contemporary reality ${ }^{2}$.

The impulse which triggered the local elite into more resolute public activity, going beyond the cultural and educational initiatives, came with the year 1903, which saw major political shifts in the Balkans and Austria-Hungary. Aside from the events such as the May Coup in Serbia or the Ilinden Uprising in Macedonia against the Turks, in the Habsburg autonomous Croatia-Slavonia the authoritarian regime of Count Károly Khuen-Héderváry (1883-1903) came to an end³ ${ }^{3}$ In Bosnia, Béni Kállay (1839-1903) died, after having presided over the occupation administration since 1882 as the Austro-Hungarian minister of finance, and having pursued repressive policies against the local Slavic communities. The centralist policies of B. Kállay never hampered the expansion of the Bosnian Slavic cultural and national movements ${ }^{4}$. They developed rapidly and resulted in the creation of a highly connected net-

${ }^{1}$ See: C. Ruthner, Habsburg's only colony? Bosnia-Herzegovina and Austria-Hungary, 1878-1918, „SEEU Review” 2019, vol. 12, no. 1, p. 3-5.

${ }^{2}$ R.J. Donia, Bosnia and Herzegovina: the proximate colony in the twilight of empire, „Godišnjak” 2013, vol. 42, p. 197-202; S. Vervaet, Some historians from former Yugoslavia on the Austro-Hungarian period in Bosnia and Herzegovina (1878-1918): a reality of imperialism versus the golden years of the Double Eagle?, „Kakanien revisited” 2004, p. 1-5; https:/www.kakanien-revisited.at/beitr/fallstudie/ SVervaet1/ [access: 21.09.2020].

3 D. Gabor, Diplomatic struggle for supremacy over the Balkan Peninsula (1878-1914). Collected studies, Sofia 2017, p. 50-52.

4 During the time of B. Kallay's rule, the authorities attempted to impose over the local peoples a formula of a political nation of Bosnia, encompassing the multitude of Slavic ethnic groups. This nation was defined within the framework of loyalty to the emperor, and against the expansion of the national ideologies, both Croatian and Serbian, including reinterpretation of cultural and historical heritage of local 
work of cultural and educational associations, public reading rooms and national education institutions ${ }^{5}$. Although the Muslim communities were somewhat lagging in this development, due to their certain isolation and limited resources ${ }^{6}$.

B. Kállay's successor, Istvan Burian, attempted to alleviate gradually the regimes's control over the public life. In March 1907 the authorities changed the regulations regarding newspaper print. The obligatory concessions were withdrawn, being replaced by the obligation to inform the authorities on the new print eight days prior to its issue. Periodicals, if more or less ephemeral, flourished in Bosnia, on politics, literature, culture, religion, and were intended for the local readers. It has to be said that their outreach was quite limited due to the fact that the majority of local population was not literate at that time. According to the contemporary statistics, the level of illiteracy in Bosnia reached a figure of $90 \%$. On the other hand, Bosnia was experiencing an economic boost, mostly as a result of the Austro-Hungarian investments in infrastructure and transport. A Slavic intelligentsia existed as well, in rather small representation, yet very aware of their distinct identity, and with a varied level of connection to the Empires's institutions. A local bourgeoisie was also gradually emerging, earning their fortunes in commerce and financial services, offered predominantly to the Habsburg administration ${ }^{7}$. The newspapers were the first channel where the incipient young Slavic elite were able to voice their beliefs. Most of the Christian activists were inclined to one of the national ideologies, either Serbian or Croatian. This was regarded as a natural consequence of the existing cultural and historical bonds between both the Bosnian Orthodox communities and Serbia, as well as the Catholics and Croatia. The young Muslim elite on the other hand prioritised the task to transform the religious autonomy in such a way, that it would guarantee certain protection from the religious, cultural and national expansion from the Christian side 8 .

A turning point for the political activities of these circles came in two years following the annexation of Bosnia by Austria-Hungary, when a limited version of political pluralism was introduced, based on the workings of the Bosnian parliament, the Diet or Sabor (1910-1914). Each of the local parliamentary groups addressed their respective religious communities for votes, their programmes however, were mainly focused on the ethnic and national slogans. The elite of the Bosnian Muslims created the

\footnotetext{
Muslim population. The programme failed however, due to the lack of support from the local intelligentsia. Furthermore, the governors themselves lacked any consensus with regards to the development of the main concept, as the Hungarian side saw it as a threat to their interests in Bosnia; A. Feldman, Kállay's dilemma on the challenge of creating a manageable identity in Bosnia and Herzegovina (1882-1903), „Review of Croatian history” 2017, vol. 13, p. 104-106; T. Kraljačić, Kalajev režim u Bosni i Hercegovini (1882-1903), Sarajevo 1987, p. 195-201.

5 Ibidem, p. $155-170$.

6 Ibidem, p. 355-356.

7 F. Hauptman, Privreda i društvo Bosne i Hercegovine u doba austrougarske vladavine (18781918), in: Prilozi za istoriju Bosne i Hercegovine, vol. 2, Sarajevo 1987, p. 113.

8 E. Fejzić, Political thought in Bosnia and Herzegovina during Austro-Hungarian rule, 1878 1918, „East Central Europe” 2012, vol. 39, no. 2-3, p. 217.
} 
Muslim National Organisation (1906). The party achieved a stable position and withstood the secession of a group of its active members in 1910. The secessionists established the Muslim Democracy, which failed to influence the electorate in any discernible manner, much like the Muslim Progressive Party (independent). The Bosnian Serbs rallied under the Serbian National Organisation (1907; SNO) and the smaller Serbian People's Independent Party. The Bosnian Croats in turn supported their own Croatian People's Union (1910) or the Croatian Catholic Association (1910), until the two parties merged in $1912^{9}$.

The Muslim and Croatian communities were predominantly satisfied with the Habsburg administration and their policies. The political elites of the Muslim and the Bosnian Catholic circles, with the exception of a number of independent political thinkers, were generally convinced that the imposed political system of AustriaHungary served to protect their interests and allowed room for their own manoeuvre. The Orthodox communities on the other hand, were rather divided with regards to the above, due to the significant influence of the groups inclined against the Habsburg regime. Heated debates continued within the particular communities, regarding the legal and institutional organisation of the Bosnian public life. A consensus on the current status and the future of Bosnia within the Monarchy was lacking. While the Orthodox and Catholic communities were inclined towards the pan-Serbian (the Greater Serbia) or pan-Croatian visions respectively, the Muslim canvassers argued mostly about the most efficient ways to secure the religious and cultural identity of the followers of Islam ${ }^{10}$.

As a matter of fact, the main part of Bosnian Muslim activists focused on conserving the status quo, which protected their religious distinctiveness within a culturally unfamiliar state. Politically, this amounted to the struggle to maintain the social and economic structure based on the dominant role of the traditional Muslim houses. The most educated and affluent Bosnian Muslims were poor grounds for any anti-systemic or revolutionary agitation. Their approach was quite pragmatic in their attempts to improve their particular standing, relative to the Christian communities. The political disputes divided the Muslim groups into two main factions; the traditionalist and the innovative. The core of this division lied in their differing attitudes to the certain types of the autonomy for the Muslim religious and educational institutions (wakf), and to the issue of land possession. On the other hand, both sides emphasised the need to act in a reserved, evolutionary manner and relied on the authorities' initiative with regards to the agrarian issue. In both of the mentioned disputes the conservative approach gained the upper hand due to the support from the state. The authorities believed that conserving the separate Muslim institutions was the way to better control their com-

9 See: M. Imamović, Pravni položaj i unutrašnjopolitički razvitak BiH od 1878. do 1914., Sarajevo 2007.

10 T. Kraljačić, Kalajev režim, p. 15. 
munities. Such structures were intended to be the foundation of the Austro-Hungarian influence in Bosnia, and to support the solutions imposed be the regime ${ }^{11}$.

The writer, poet and politician Safvet-beg Bašagić (Mirza Safve; 1870-1934) was regarded as the most important advocate for the rights of Muslims. He directed the activities of the Muslim Progressive Party and presided over the Diet in 1910-1914. His followers were many intellectuals devoted to the Muslim education (Muhamed Hadžijahić), administration (Mehmed-beg Kapetanović Ljubušak, mayor of Sarajevo in 1893-1899), as well as writers and newspaper editors (Osman Nuri Hadžić; 18691937, Alija Hotić). Some of them displayed a kind of sympathy towards cooperation with Croatian cultural circles or called for a balanced religious custody of the Sultan and the Monarchy over the local Muslim community. Among the few critics of the state policies, we should mention the philosopher Salih Kazazović (1873-1943) and one of the most prominent local politicians, Šerif Arnautović (1847-1935), who fought against the repressions of B. Kallay's regime, not eschewing the cooperation with Serbian communities ${ }^{12}$.

The crucial part in the discourse was comprised of the organisation outlines of the Bosnian Islam as the most important element of the identity of the local Muslims. On the one hand, Osman Nuri Hadžić advocated for a new religious revival among the Muslims, in relation to local communities and in the spirit of pan-Islamism. On the other hand, the journalist and politician Sakib Korkut (1884-1929) argued that to empower the Muslim communities in Bosnia, the adoption of a democratic model of religious management was essential. S. Korkut advocated for structural reforms, based on a collective body of the leaders of the particular Muslim communities. In his opinion, the local leaders were expected to display concrete administrative and managerial skills and were accountable directly to the members of their communities. He believed that the influence of the traditional families from the Ottoman period, which dominated over particular, local communities (with real material benefit), should be limited. S. Korkut also emphasised the fact that religious institutions should focus more attention on developing educational and cultural initiatives to integrate their followers ${ }^{13}$.

Among the Muslim elites of the period at hand, certain voices were also surfacing on the necessity to define some sort of ethnic and cultural distinctiveness, with reference to the local believers. A number of influential individuals elaborated on this issue, such as the clergyman and writer Muhamed Emin Hadžijahić (1837-1892), Mehmed-beg Kapetanović Ljubušak, Šerif Arnautović or, at the early stages of his activity, Safvet-beg Bašagić. However, it would seem that there never emerged any

11 E. Fejzić, Political thought, p. 205-206; T. Kraljačić, Kalajev režim, p. 402.

12 See: E. Zgodić, Bosanska politička misao, austrougarsko doba, Sarajevo 2003, p. 27-305.

13 O.N. Hadžić, Islam i kultura, Zagreb 1894, p. 34-36; S. Korkut, Kako da razvijemo rad u narodu?, „Gajret” 1910, no. 7-8, p. 108; S. Korkut, Dvije preuzete rezolucije, „Misbah” 1913 (May-June), no. 14-15, p. 106. See: M. Hadžijahić, Od tradicije do identiteta: geneza nacionalnog pitanja bosanskih muslimana, Zagreb 1990, p. 174; E. Redžić, Sto godina muslimanske politike, Sarajevo 2000, p. 48. 
concrete idea. Osman Nuri Hadžić and Šukrija Kurtović (1890-1973) emphasised the need to establish a national identity, based on the legal and religious distinctiveness of the Muslims in Austria-Hungary. Mehmed-beg Kapetanović Ljubušak was regarded as the first theorist of the ethnic unity of the Bosnian Muslims. He claimed that the followers of Islam were a separate ethnic group, with a degree of connection to the Serbs and Croats due to their shared affiliation to, as he would phrase it, the heroic Yugoslav people ${ }^{14}$. Safvet-beg Bašagić in turn, wrote on the historical roots of what the termed Bosnianism, creating a synthesis of the history of Muslim peoples, based on the legacy of the mediaeval, Osman and Austro-Hungarian Bosnia. He saw a continuity, from the Bosnian aristocracy of the middle ages to the 19th century Muslim elite of land owners and religious leaders. Safvet-beg Bašagić argued, that there existed a literary heritage, drawing on the tradition of the Bosnian language, firmly embedded among the local people ${ }^{15}$. Another advocate of Bosnianism, Šerif Arnautović, focused his writings on the political autonomy, the achievement of which was essential to Bosnia in order to evade the risk of the Muslim people becoming assimilated by the Serbs and Croats ${ }^{16}$.

Without doubt, the majority of the Muslim activists never identified with creating a separate Bosnian ethnos. According to their origins, education or personal connections, the particular theorists were rather inclined to cooperate with the Croats or, less frequently, the Serbs. It was in such a context, that the two renown journalists, Smailaga Ćemalović (1884-1945) and young student Šukrija Kurtović (1890-1973) were regarded as Serbophiles ${ }^{17}$. The pro-Croatian attitudes on the other hand, were expressed by the politician and financier Fadil Kurtagić (1889-1958) or the already mentioned Nuri Hadžić, a student of law in Vienna and Zagreb. Safvet-beg Bašagić himself, frequently dubbed ,The father of Bosnian renaissance” in contemporary Bosnian historiography, had studied the Arabic and Persian languages in Vienna, and lectured in Zagreb on the Oriental languages. He also had connections with the artistic milieu, gathered around the Croatian poet Silvije Strahimir Kranjčević (1865-1908), who venerated the beliefs of Ante Starčević and the nationalist Croatian Party of Rights. As the president of the Diet in Sarajevo, S. Bašagić initially advocated for the political autonomy of Bosnia, even though he later shifted to the idea of the Bosnian-Croatian

14 M. Ljubušak Kapetanović, Budućnost ili napredak muhamedovaca u Bosni i Hercegovini: namijenjeno za pouku i ogled nekoj našoj braći Bošnjacima i Hercegovcima. Sarajevo 1893, p. 24.

15 S. Bašagić, Kratka uputa u prošlost (od god. 1463-1850), Sarajevo 1900; idem, Bošnjaci i Hercegovci u islamskoj književnosti: prilog kulturnoj historiji Bosne i Hercegovine, Sarajevo 1986, p. 8.

16 See: A. Jahić, Usponi i padovi zagonetnog Mostarca - skica za biografiju Šerifa Arnautovića, „Arhivska praksa” 2015, no. 18, p. 461.

17 See: Š. Kurtović, O nacionalizovanju muslimana, Sarajevo 1914. As a student of the University of Graz, Smail-aga Ćemalović (1884-1945) worked for the „Musavat” newspaper (editor; 1906-1911) and was associated with the concept of religious patronage of Sultan over the Bosnian Muslims. In 1912 he became the founder of the „Srpska omladina” newspaper (Sarajevo). He criticised the loyal attitude of representatives of Muslim religious autonomy towards the Habsburg monarchy. 
union within the Habsburg Empire. His former stance was to criticise the Croatian national particularism in Bosnia, and argue that the Muslims should be regarded as a separate group in the perfectly ethnic sense. However, he later decided that such an idea of separation pertained rather to the emotional sphere, which should not become codified $^{18}$.

In the field of culture, Osman Nuri Hadžić should be mentioned as the advocate of cooperation with the Croats. His first article on the Bosnian folk traditions were published in Croatian periodical. In 1894, together with the Croatian writer, journalist and member of the nationalist Party of Rights, Ivan Aziz Miličević, under the shared pseudonym Osman-Aziz, he began to publish short stories related to the traditions of the Muslim folk. On the other hand, towards the end of the World War I, Alija Hotić wrote, that the Bosnian Muslims were actually Croats in the ethno-cultural sense, and that the majority of Bosnian territory were an integral part of Croatian land. A. Hotić was mistrustful of the idea of Serbian-Croatian cooperation, and argued that the Muslims should rather identify with the Croats, whom he saw as presenting a more open identity than was the case with the Serbs ${ }^{19}$.

The political activity of the Croatian elite in Bosnia relied on the conservative Croatian People's Union, founded by the historian and lawyer Ivo Pilar (1874-1933), or the clerical Croatian Catholic Association, identified mostly with the figure of the pan-Bosnian metropolitan bishop Josip Štadler (1843-1918). Ivo Pilar was an adversary of the clerical circles in the discourse on the general outline of the Croatian national identity within Bosnia. In his opinion, the reliance of the political life of the Croats solely on the authority and structures of the church was an impediment to the assimilation of the non-Croat people, especially the increasingly secular Muslim elite, which perceived a strong bond with the Croatian culture. Contrary to this, the bishop regarded Catholicism as the defining element of the Croatian national identity. The dispute continued until 1912, when it became evident that the feud weakened both sides, and a unified political grouping was formed with the followers of I. Pilar as the leaders ${ }^{20}$. The newly united party founded its policy on the expansionist concept of the Croatian nationalism and was opposed to the postulates to autonomise Bosnia. The notion of distinctive Bosnian traditions was rejected, even though it was being upheld by the Franciscan friar Antun Knežević (1834-1889), a scholar with a well-earned reputation in the ethnography and language of central Bosnia. In historiography, he was characterised as a Bosnian intellectual who could comprehend and nourish the cultural distinctiveness of the population of Bosnia, regardless of the varied ethnic backgrounds or religious affiliations. A. Knežević referred to the concepts of

18 E. Zgodić, Bosanska politička misao, p. 125-130.

19 Ibidem, p. 232.

20 L. Đaković, Političke organizacije bosanskohercegovačkih katolika Hrvata, Zagreb 1985, vol. 1, p. 176; J. Krišto, Ivo Pilar, nadbiskup Josip Štadler i Hrvatska narodna zajednica, „PILAR: časopis za društvene i humanističke studije" 2008, vol. 3, no. 6(2), p. 47-50; see: E. Zgodić, Politička misao Josipa Štadlera, „Glasnik Rijaseta Islamske zajednice u BiH” 2001, no. 5-6. 
the Illyrian movement, emphasising the historical continuity, underlying the Bosnian identity since the middle ages. He criticised the national integralist ideas, both Serbian and Croatian, which he regarded as puppet movements serving the interests of foreign powers. Among the ethnic Bosnians he discerned three equally valid religious groups. He never saw the heterogeneous ethnic and religious structure of Bosnian population as an obstacle to the establishment of a unified political or administrative entity, encompassing the historical Bosnian land ${ }^{21}$.

As a representative of the Roman Catholic hierarchy, the archbishop J. Štadler regarded those beliefs which emphasised the existence of a distinct Bosnian consciousness as a threat to the Croatian national movement and to Catholicism as well. He was a spokesman of the pan-Croatianism, which he combined with proselytism. What he postulated, was the pursuit of integrally understood nationalism, and the accompanying catholicisation of the Bosnian Muslims. One of the striking features of J. Štadler's views was his negative perception of the Islam. He insisted on the escalation of missionary activity against the Muslims, who were supposed to become Catholic and join the pan-Croatian programme as soon as possible. In his view, a Croat could only be a Catholic. J. Štadler's political clericalism had grown from his conviction that the structures of the Catholic church must play a crucial part in the development of the national programme in the Bosnian multicultural environment. He regarded Catholicism as the moral and ideological backbone of the national movement. His views were criticised by both the Muslim and Serbian communities, since he insisted on the catholicisation of the Orthodox population as well. However, the bishop renounced any accusations of aggressive proselytism, claiming that it was never his intention to forcefully convert anyone ${ }^{22}$. Regarding the national cause, the bishop was quite close to the nationalist Ante Starčević and envisioned the incorporation of Bosnia into „Mother Croatia” within Austria-Hungary. He emphasised the need to build the national identity in the atmosphere of conflict with the other ethnic and religious groups, arguing that the imminent threat was a sine qua non for the efficient establishment of national unity ${ }^{23}$.

In the pan-Croatian political ideology of Ivo Pilar, both the Bosnian Catholics and Muslims were regarded as Croats in the national context. In his writings he denied the thesis of the Bosnian distinctiveness in the historical, cultural or ethnic sense. According to him, Bosnia was part of the Croatian land since the first Slavic settlements in early middle ages up to the 20th century. He only recognised the existence of Serbian people in Bosnia and attributed to them a separate national consciousness.

21 E. Fejzić, Political thought, p. 218-219.

22 K. Šegvić, Štadler osniva „Hrvatski dnevnik”, in: Spomenica Vrhbosanska 1882-1932, Sarajevo 1932, p. 106-107. See: Z. Grijak, Politička djelatnost vrhbosanskog nadbiskupa Josipa Štadlera, Zagreb 2001, p. 301.

${ }_{23}$ Z. Grijak, Političke i diplomatske okolnosti pokušaja uklanjanja nadbiskupa Štadlera iz Sarajeva 1913. godine, „Croatica Christiana periodica: časopis Instituta za crkvenu povijest Katoličkog bogoslovnog fakulteta Sveučilista u Zagrebu” 2004, vol. 54, p. 150-151. 
I. Pilar's distinction between Croats and Serbs was defined by the differences in religion, culture and historical traditions. In his view, the national characteristics of the Serbs were formed upon the foundation of the Orthodoxy, while the Croatian ones grew upon the Catholicism, Bogomilism and Islam. His national reflections were inspired by the conviction that the Croats had been endowed with a certain civilisational mission, and were meant to play a vital part in the modernisation of the political, ethnic relations within the Habsburg Monarchy. He believed that they were the only national group able to ensure a peaceful consolidation of South Slavdom within the Empire, through a national union of Croatia, Slavonia, Dalmatia and Bosnia ${ }^{24}$.

In his prognosis, I. Pilar outlined the perspectives of the consolidation of the Croatian national life on the territories which he identified with the Croatian history, culture and language. He rejected the concepts of unity, such as the Illyrian or Yugoslav ones, which had been formulated by J. Strossmayer (1815-1905). In his opinion, a nationally homogeneous Croatia was meant to protect the southern borders of the Habsburg (German) Empire, to create a barrier against the expansion of the Orthodoxy, and establish a counterweight proposal to the projects of Slavic unity formulated in Serbia ${ }^{25}$.

The most prominent political organisation of the Bosnian Serbs under the AustroHungarian rule, the autonomist Serbian National Organisation (SNO), housed three conflicted political currents, rallied around two anti-Habsburg periodicals: "Narod" (1909) and "Otadžbina", and the so-called bastion of the Serbian conformism, the "Srpska riječ" newspaper. The first group (also called the Mostar Group) was considered the most influential among the Serbs, and identified with the nationally extremist beliefs of the physician Uroš Krulj (1875-1961) or the journalist Risto Radulović (Rindo, 1880-1915), both born in Mostar. In unison, they criticised what they saw as anti-Serbian activity of the Habsburg administration in Bosnia. According to R. Radulović, the Empire had established ,a colonial system" in Bosnia, meant to deprive the Serbs of their liberty and gradually germanise them. He bitterly criticised all Slavic activists who accepted the political status quo. As he wrote in 1912, the urbanised and culturally most dynamic part of the Serbian national element lacked proper

24 In some works of Yugoslav historiography, I. Pilar was regarded as a representative of Social Darwinism school of thought. In his view, the history was determined by natural laws, which defined the fate of peoples and states during the course of the ages. Special attention was drawn to the rigorous laws governing time and space. One of them was the law of territorial expansion, as the foundation of survival within the given space. In this sense, I. Pilar was an advocate of the policy of broadening the Croatian autonomy by the incorporation of Bosnia. He believed that a nationalist expansion was the sine qua non of the longevity of nation-state communities. On the other hand, he criticised the politics of the Great Serbia, claiming that it went far beyond the natural boundaries; I. Pilar (L. v. Südland), Južnoslovensko pitanje, Varaždin 1990, p. 316, 412-413; see: T. Jonjić, Ivo Pilar prema rasnom učenju i eugenici, "PILAR: časopis za društvene i humanističke studije" 2016, vol. 11, no. 21(1), p. 61.

${ }^{25}$ S. Đurašković, Croatian intellectuals and World War I: between Croatia as bulwark of Mitteleuropa towards the West and the other way around, in: Intellectuals and World War I: A Central European perspective, eds. T. Pudlocki, K. Ruszała, Cracow 2018. p. 111-131. 
conditions for their own development, and was thus in danger of being shorn of their national characteristics. R. Radulović was regarded as the central figure of the Serbian anti-occupation movement. His publishing was highly influential among the revolutionary inclined activists of the clandestine organisation Young Bosnia (1911-1914), even though he himself was not in favour of any radical socio-political change. As opposed to the more revolutionary canvassers, he thought that the main engine of change should reside in the urban elites, rather than the rural people, in spite of the latter being the majority of the Serbian population in Bosnia ${ }^{26}$.

The anti-Habsburg attitudes were also represented by the activists clustered around the "Otadžbina" newspaper printed in Banja Luca. The main political role was played by Petar Kočić (1877-1916), seen as the leader of the Serbian anti-Habsburg faction in the Diet in Sarajevo (1910-1914). Contrary to the other influential politicians in SNO, P. Kočić advocated for a radical agrarian reform in order to politically emancipate the Orthodox peasantry, whom he regarded as the pillar of Serbian identity $^{27}$. The official tone of the SNO's activity, however, was moderated by the canvassers regarded as conformist (Gligorije Jeftanović, 1840-1927; merchant Vojislav Šola, 1861-1921; lawyer Milan Srškić, 1880-1937). In their contributions to the newspaper "Srpska riječ" they attempted to find a code of conduct towards the Habsburg administration, regardless of the pan-Serbian inclinations of the other party members. This environment was popular among the bourgeoisie, the public employees and influential entrepreneurs. Even though the social basis of SNO was mostly comprised of the Serbian peasantry, the party cooperated within the Diet with the Muslim land owner circles. Their official goal was to secure the political and cultural autonomy for the Bosnian Serbs, without any mention whatsoever regarding the agrarian issue ${ }^{28}$. Their lack of interest in the agrarian reform resulted in a stark critique from the Serb People's Independent Party (1907) founded by Lazar Dimitrijević. In his articles in the "Dan" periodical, he demanded radical transformations in the rural areas, in close cooperation with the state power. According to his argumentation, the peasantry's loyalty to the state was the necessary condition on the realisation of the agrarian reform, which would alleviate their feudal liabilities. However, the newspaper did not last long on the political market, as the Serbs refused to recognise its unequivocally pro-Habsburg inclinations ${ }^{29}$.

26 R. Radulović, Seljak i politika, „Pregled” 1912, no. 2, p. 9-10; idem, O organizaciji, „Narod” 1907 , no. 47, p. 5 . On the question of the attitude of Serbian democratic and national circles towards the agrarian issue in Bosnia, see: I. Mišković, Uticaj časopisa "Pregled" na društveni i kulturni život Bosne i Hercegovine kroz pisanje o agrarnoj problematici 1910-1913, „Historijski pogledi” 2019, vol. 2, no. 2, p. $120-132$.

27 P. Kočić, Težak, “Otadžbina” 1907, no. 1; https://www.rastko.rs/rastko-bl/kocic/pkocic-lirske proze_1.html [access: 21.09.2020].

$\overline{28}$ A. Đozić, Bosanskohercegovački suverenitet u političkoj djelatnosti MNO (Muslimanske narodne organizacije), ,Znakovi vremena” 2007, vol. 10, no. 35/36, p. 231-232.

29 E. Fejzić, Political thought, p. 35. 
Despite the SNO management's loyalty to Vienna, the party's ranks swelled with advocates of the pan-Serbian ideas, which posed a threat to the integrity of the Habsburg Monarchy. They would emphasise the cultural, historical and national superiority of the Serbs in Bosnia, more often than not regarding with contempt the attempts at political emancipation by the Bosnian Muslims. Such an attitude is evident in the writings of Petar Kočić (1877-1916), the lawyer Nikola Stojanović, Đorđe Lazarević, the ethnographer and geographer Jefto Dedijer (1880-1918), the historian Vladimir Ćorović (1885-1941) or the writers and activists of the Young BosniaBorivoj Jevtić (1894-1959) and Vladimir Gaćinović ("Vlado", 1877-1916). All of the above publicists emphasised the primary role of the Serbian national interest in the political activity of the SNO. However, they differed as to their views on the matters of the society ${ }^{30}$. Vaso Pelagić (1838-1899), a socialist activist, advocated for radical, yet evolutionary social solutions among the Muslims and Serbs, which could open a real integration of Muslim people with the Serbian national programme. On the other hand, Dimitrije Mitrinović (1887-1953), the poet, philosopher and one of the most prominent activists of Young Bosnia, argued towards the establishment of pluralist society in Serbian Bosnia, inspired by Western European values. He criticised the provincial patriarchalism, which he saw as the dominant element of social relations in Bosnia, as a hindrance to the implementation of new solutions. In the opinion of D. Mitrinović, the education, technology and progressive thinking - the foundations of the civilisational power of the West - should be applied to liberate the Serbian national life from obsolete arrangements, and to support the Serbs in tacking their contemporary challenges. In his writings, D. Mitrinović combined national ideology with individuality and personalism. In his opinion, the daily functioning of a nation or state should never constrict the rights of an individual. Contrary to the above, R. Radulovic would consider the community work to be the life goal for each individual ${ }^{31}$.

The description of ideological life in Bosnia at the turn of the 19th century would not be complete without the Social Democratic Party of Bosnia (1909), even despite it having been rather scant. Its activity was hampered, not only due to the lack of a significant large-industry working class in Bosnia, but also as a result of the repression from the local political establishment and administration (even though the party had never, until the aftermath of the Great War, questioned the legitimacy of the Habsburg rule). The Social Democratic Party of Bosnia was the only political grouping inclined towards multi-ethnicity, and forwarded a programme of recognition of the rights of the individual, regardless of ethnicity or religion. A group of young activists such as Dušan Glumac or Jovo Jakšić attempted to create an alternative to the dominant

30 Ibidem, p. 213; E. Zgodić, Vladimir Ćorović: panserbizam, Bosna i Bošnjaci: prilog kritičkoj historiji socijalne i političke misli u Bosni i Hercegovini; http://www.diwanmag.com.ba/arhiva/diwan5_6/ sadrzaj/sadrzaj8.htm [access: 26.09.2020].

31 V. Pelagić, Izabrana djela, vol. 1, Sarajevo 1971, p. 233, 384; D. Mitrinović, Nacionalno tlo i modernost, Sarajevo 1908, p. 45-48. 
political and national narrative. Having rejected the nationalist concepts, they introduced into the local public life the ideas of the equality of rights for all ethnic and social groups. In their community projects regarding Bosnia and South Slavdom, the term Serbo-Croats was in use, and they advocated for the Muslim elite to participate in the equal creation of the Yugoslav or the regional-federation solution ${ }^{32}$. Without doubt, their social democratic postulates stood a good chance of flourishing with regards to the issues of the society. However, their ideas for moral change, such as the emancipation of women, were rather unlikely to gain any real support. The movement failed with regards to winning the rural electorate, despite their relatively radical postulates on the agrarian reform. In fact, the socialist milieu never sought the alliance of peasantry in their struggle for social change. Their attempts at the cooperation with the other socially radical figures of the Serbian national politics, such as Petar Kočić, were also in vain ${ }^{33}$.

The Slavic political elites in Bosnia at the turn of the 19th century were formed in the environment of accelerated, and imposed process of Europeanisation in various aspects of social life. The new mechanisms of socio-economic life came into being under the influence of multiple social tensions. The socio-political groupings attempted to establish themselves in spite of the lack of civil rights, and came under considerable political and cultural pressure from the rivalled subjects - Serbs and Croats. The Habsburg Empire regarded Bosnia as a protectorate, to be administered in a centralised, militarist manner. The local people were subjugated to foreign administration, tasked with the adaptation of the conquered territory to the reality of the Dual Monarchy. The growing influence from Serbia, which at that time was formulating its national programme of the territorial unity, translated into increasingly radical attitudes among the public.

In both journalism and political publishing, the representatives of the Bosnian intelligentsia were drawing on the legacy of European nationalism, liberalism or socialism. However, it was the national ideologies, formulated under such influence as Social Darwinism, that became the true landmarks for their public activity. The community interests which they attempted to pursue in practice never abolished any of the previously existent divisions in Bosnia, but rather proceeded to phrase them in another manner. As was made evident during the 1910 Diet elections, the local political scene had shortly become dominated by the ethnic particularities, overlying the religious divisions already in place. The political space for any alternative concepts was critically lacking, despite their potential to integrate the local population over and above the existing divisions. The controversial social issues became subordinate to the national programmes and current political calculations. With the exception of the Social Democratic Party, such issues were never voiced as an integral part of the pro-

32 E. Fejzić, Rana bosanskohercegovačka ljevica i njene socijalno-političke preokupacije, „Diwan 2007, vol. 10, no. 21-22, p. 163-168; idem, Political thought, p. 222-226.

33 Ibidem, p. 227. 
gramme of any political grouping. Any ideological novelties borrowed from the West were regarded in much the same way. On the Bosnian grounds, they would invariably become rationalised within the framework of national or ethno-religious particularities.

\section{BIBLIOGRAPHY}

Bašagić Savfet-beg, Kratka uputa u proslost (od god. 1463-1850), Sarajevo 1900.

Bašagić Savfet-beg, Bošnjaci i Hercegovci u islamskoj književnosti: prilog kulturnoj historiji Bosne i Hercegovine, Sarajevo 1986.

Donia Robert J., Bosnia and Herzegovina: the proximate colony in the twilight of empire, „Godišnjak” 2013, vol. 42, p. 197-202.

Đaković Luka, Političke organizacije bosanskohercegovačkih Hrvata, vol. 1, Zagreb 1985.

Đozić Adib, Bosanskohercegovački suverenitet u političkoj djelatnosti MNO (Muslimanske narodne organizacije), „Znakovi vremena” 2007, vol. 10, no. 35/36, p. 226-240.

Đurašković Stevo, Croatian intellectuals and World War I: between Croatia as bulwark of Mitteleuropa towards the West and the other way around, in: Intellectuals and World War I: A Central European perspective, eds. T. Pudlocki, K. Ruszała, Cracow 2018. p. 111-131.

Fejzić Elvis, Political thought in Bosnia and Herzegovina during Austro-Hungarian rule, 1878-1918, „East central Europe” 2012, vol. 39 , no. 2-3, p. 204-236.

Fejzić Elvis, Rana bosanskohercegovačka ljevica i njene socijalno-političke preokupacije, „Diwan 2007, vol. 10 , no. 21-22, p. 153-170.

Feldman Andrea, Kállay's dilemma on the challenge of creating a manageable identity in Bosnia and Herzegovina (1882-1903), „Review of Croatian history” 2017, vol. 13, p. 103-117.

Gabor Demeter, Diplomatic struggle for supremacy over the Balkan Peninsula (1878-1914). Collected studies, Sofia 2017, p. 50-52.

Grijak Zoran, Politička djelatnost vrhbosanskog nadbiskupa Josipa Štadlera, Zagreb 2001.

Grijak Zoran, Političke i diplomatske okolnosti pokušaja uklanjanja nadbiskupa Štadlera iz Sarajeva 1913. godine, „Croatica Christiana periodica: časopis Instituta za crkvenu povijest Katoličkog bogoslovnog fakulteta Sveučilista u Zagrebu" 2004, vol. 54, p. 149-189.

Hadžić Osman Nuri, Islam i kultura, Zagreb 1894.

Hadžijahić Muhamed, Od tradicije do identiteta: geneza nacionalnog pitanja bosanskih muslimana, Zagreb 1990.

Hauptman Ferdo, Privreda i društvo Bosne i Hercegovine u doba austrougarske vladavine (1878-1918), in: Prilozi za istoriju Bosne i Hercegovine, vol. 2 , no. 18, Sarajevo 1987, p. 99-211.

Imamović Mustafa, Pravni položaj i unutrašnjopolitički razvitak BiH od 1878. do 1914., Sarajevo 2007.

Jahić Adnan, Usponi i padovi zagonetnog Mostarca - skica za biografiju Šerifa Arnautovića, „Arhivska praksa" 2015, no. 18, p. 455-470.

Jonjić Tomislav, Ivo Pilar prema rasnom učenju i eugenici, "PILAR: časopis za društvene i humanističke studije" 2016, vol. 11, no. 21(1), p. 45-111.

Juzbašić Dževad, Nacionalno-politički odnosi u Bosanskohercegovačkom saboru i jezičko pitanje (19101914), Sarajevo 1999.

Korkut Sakib, Dvije preuzete rezolucije, „Misbah” 1913 (May-June), no. 14-15, p. 106.

Korkut Sakib, Kako da razvijemo rad u narodu?, „Gajret” 1910 , no. 7-8, p. 108.

Kočić Petar, Težak, “Otadžbina” 1907, no. 1; https://www.rastko.rs/rastko-bl/kocic/pkocic-lirskeproze_1. html [access: 21.09.2020].

Kraljačić Tomislav, Kalajev režim u Bosni i Hercegovini (1882-1903), Sarajevo 1987. 
Krišto Jure, Ivo Pilar, nadbiskup Josip Štadler i Hrvatska narodna zajednica, „PILAR: časopis za društvene i humanističke studije" 2008, vol. 3 , no. 6(2), p. 47-50.

Kurtović Šukrija, O nacionalizovanju muslimana, Sarajevo 1914.

Ljubušak Kapetanović Mehmed, Budućnost ili napredak muhamedovaca u Bosni i Hercegovini: namijenjeno za pouku i ogled nekoj našoj braći Bošnjacima i Hercegovcima. Sarajevo 1893.

Madžar Božo, Pokret Srba Bosne i Hercegovine za vjersko-prosvjetnu samoupravu, Sarajevo 1982.

Mišković Igor, Uticaj časopisa "Pregled" na društveni i kulturni život Bosne i Hercegovine kroz pisanje o agrarnoj problematici 1910-1913, „Historijski pogledi” 2019, vol. 2, no. 2, p. 120-132.

Mitrinović Dimitrije, Nacionalno tlo i modernost, Sarajevo 1908.

Pelagić Vaso, Izabrana djela, vol. 1, Sarajevo 1971.

Pilar Ivo (L. v. Südland), Južnoslovensko pitanje, Varaždin 1990.

Radulović Risto, O organizacji „Narod” 1907, no. 47, p. 5.

Radulović Risto, Seljak i politika, „Pregled” 1912, no. 2, p. 9-10.

Redžić Enver, Sto godina muslimanske politike, Sarajevo 2000.

Ruthner Clemens, Habsburg's only colony? Bosnia-Herzegovina and Austria-Hungary, 1878-1918, „SEEU Review” 2019, vol. 12, no. 1, p. 2-14.

Šegvić Kerubin, Štadler osniva „Hrvatski dnevnik”, in: Spomenica Vrhbosanska 1882-1932, Sarajevo 1932, p. 106-108.

Vervaet Stijn, Some historians from former Yugoslavia on the Austro-Hungarian period in Bosnia and Herzegovina (1878-1918): a reality of imperialism versus the golden years of the Double Eagle?, „Kakanien revisited” 2004, p. 1-5; https://www.kakanien-revisited.at/beitr/fallstudie/SVervaet1/ [access: 21.09 .2020$]$.

Zgodić Esad, Bosanska politička misao, austrougarsko doba, Sarajevo 2003.

Zgodić Esad, Vladimir Ćorović: panserbizam, Bosna i Bošnjaci: prilog kritičkoj historiji socijalne i političke misli u Bosni i Hercegovini; http://www.diwanmag.com.ba/arhiva/diwan5_6/sadrzaj/ sadrzaj8.htm [access: 26.09.2020]. 